\title{
Pengaruh Penambahan Minyak Atsiri Kulit Jeruk Manis pada Pengencer Tris Kuning Telur Terhadap Kualitas Semen Post-Thawing Sapi Simmental
}

\section{Influence of Addition Sweet Orange Essential Oil on Tris Yolk Extender to Quality of Post- Thawing Semen Simmental Cattle}

\author{
S. A. Sitepu* dan A. Putra \\ Program Studi Peternakan Fakultas Pertanian Universitas Pembangunan Panca Budi \\ *E-mail: sukmaaditya@dosen.pancabudi.ac.id \\ (Diterima: 16 Agustus 2017; Disetujui: 19 September 2017)
}

\begin{abstract}
ABSTRAK
Tujuan jangka panjang penelitian adalah untuk mengetahui sejauh mana kualitas semen beku Sapi Simmental meliputi motilitas, viabilitas, Membran Plasma Utuh (MPU) dan Tudung Akrosom Utuh (TAU), yang diberi minyak atsiri kulit jeruk manis pada pengencer tris kuning telur. di Laboratorium UPT-BIB Dinas Peternakan Propinsi Sumatera Utara, Jalan Jend. Gatot Subroto Km. 7 No. 225 Medan. Penelitian dilakukan pada bulan Juni 2017. Materi yang digunakan pada penelitian ini adalah semen segar Sapi Simmental, pengencer tris kuning telur dan minyak atsiri kulit jeruk manis. Rancangan percobaan yang digunakan dalam penelitian adalah rancangan acak lengkap (RAL) non faktorial dengan 4 perlakuan dan 5 ulangan. Perlakuan yang diberikan adalah penambahan minyak atsiri jeruk manis $0,25 \%, 0,5 \%, 0,75 \%$ dan $1 \%$. Hasil penelitian menunjukkan perlakuan terbaik pada penelitian adalah penambahan minyak atsiri kulit jeruk manis sebesar 1\% yang dapat mempertahankan kualitas semen Sapi Simmental sebelum maupun sesudah pembekuan (Post Thawing).
\end{abstract}

Kata kunci: jeruk manis, minyak atsiri, post-thawing, simmental, tris kuning telur

\section{ABSTRACT}

The long-term objective of the study was to determine the extent to which frozen semen quality of Simmental Cattle included percentage Motility, viability, membrane integrity and acrosome integrity which was given essential oils of sweet orange peel in tris yolk. at UPT-BIB Laboratory of North Sumatra Veterinary Services, Jalan Jend. Gatot Subroto Km. 7 No. 225 Medan. The research was conducted in June 2017. The material used in this research is fresh semen of Simmental Cattle, tris yolk extender and essential oils of the sweet orange peel. The experimental design used in the study was a complete non-factorial randomized design (RAL) with 4 treatments and 5 replications. The treatment given is the addition essential oils of the sweet orange peel of $0.25 \%, 0.5 \%, 0.75 \%$ and $1 \%$. The results showed that the best treatment in the study was the addition 1\% essential oils of sweet orange peel which can maintain the quality of Simmental semen before and after freezing (Post Thawing).

Keywords: essential oil, post-thawing, Simmental, sweet orange, tris yolk

\section{PENDAHULUAN}

Kebutuhan akan protein hewani, seperti daging sapi di Indonesia masih belum terpenuhi. Untuk memenuhi kebutuhan tersebut perlu diwujudkan berbagai kebijakan operasional yang telah ditetapkan, antara lain meningkatkan mutu daging sapi potong, membantu permodalan bagi peternak, pengendalian penyakit reproduksi dan kesehatan ternak, pengembangan pakan serta mengembangkan mutu bibit sapi potong. Inseminasi Buatan (IB) adalah suatu program pemuliabiakan ternak yang kompleks mulai dari organisasi, penyuluhan, produksi semen, deteksi birahi dan IB (deposisi semen kedalam saluran reproduksi ternak betina) sampai evaluasi keberhasilan IB. 
Salah satu faktor keberhasilan dari IB adalah kualitas semen beku yang digunakan. Kualitas semen beku yang dimaksud adalah daya fertilitas optimum spermatozoa. Untuk mempertahankan daya fertilitas optimum, spermatozoa harus dipreservasi atau diawetkan untuk beberapa saat sesudah penampungan, karena itu semen perlu dicampur dengan larutan pengencer yang menjamin kebutuhan fisik dan kimianya (Toelihere, 1993).

Pengencer tris kuning telur sangat umum digunakan dalam proses preservasi dan kriopreservasi semen berbagai jenis hewan dan ternak. Pengencer Tris tersusun atas: tris, asam sitrat, fruktosa dan akuabidest. Tris hidroxymethil aminomethan $\left(\mathrm{C}_{4} \mathrm{H}_{11} \mathrm{NO}_{3}\right)$ banyak digunakan sebagai buffer untuk semen beku (Rizal dan Herdis, 2008). Jika dibandingkan dengan pengencer komersial seperti andromed, kualitas tris kuning telur masih lebih rendah namun harga pengencer andromed jauh lebih mahal dibanding tris kuning telur (Salmah, 2014). Penelitian dengan menggunakan pengencer tris kuning telur ditambah bahan lain yang terbukti dapat meningkatkan kualitas semen Sapi Simental telah banyak dilakukan antara lain dengan pemberian susu (Widya, 2011), raffinosa (Gunawan dan Kain, 2008), namun ada pula yang kurang efektif seperti penambahan air kelapa (Anggreani, 2005).

Adanya mikroorganisme pengganggu seperti bakteri didalam semen beku Sapi Simental merupakan salah satu pembatas terhadap keberhasilan IB. Bakteri yang terdapat di dalam semen beku Sapi Simental dapat berasal dari kuning telur. kuning telur rentan terhadap serangan bakteri seperti salmonella dan staphylococcus (Yuwanta, 2010). Hal ini akan berpengaruh terhadap ketahanan semen yang menggunakan kuning telur sebagai bahan pengencernya. Kontaminasi bakteri juga dapat terjadi pada saat koleksi semen yang berasal dari organ reproduksi jantan, penanganan selama proses pengenceran semen dan lingkungan (Toelihere, 1993).

Minyak atsiri dapat dimanfaatkan sebagai antibakteri. Salah satu minyak atsiri yang mengandung antibakteri adalah yang berasal dari kulit jeruk manis. Minyak atsiri kulit jeruk manis mengandung komponen utama antara lain limonena, linalool, pinena dan mirserna (Agusta, 2010). Diantara komponen tersebut seperti limonene dan linalool bersifat toksik pada bakteri (Fisher dan Phillips, 2006). Dengan penambahan minyak atsiri jeruk manis pada pengencer tris kuning telur diharapkan dapat diperoleh semen beku Sapi Simmental berkualitas baik yang dapat menghambat pertumbuhan bakteri, mampu mempertahankan kualitas dan daya tahan hidup spermatozoa dalam semen beku Sapi Simmental dengan angka fertilitas tinggi.

\section{METODE}

\section{Materi Penelitian}

Materi yang akan digunakan pada penelitian ini adalah semen Sapi Simmental dan bahan pengencer yang ditambahkan berbagai level minyak atsiri yang nantinya akan menghasilkan semen beku Sapi Simmental. Setelah itu dilakukan pengamatan sehingga diperoleh data penelitian berupa karakteristik kualitas semen Sapi Simmental post thawing.

\section{Tempat dan Waktu Penelitian}

Penelitian ini akan dilakukan di Laboratorium UPT-BIB Dinas Peternakan Propinsi Sumatera Utara, Jalan Jend. Gatot Subroto Km. 7 No. 225 Medan. Penelitian dilakukan pada bulan Juni 2017.

\section{Bahan dan Alat}

Bahan penelitian yang digunakan yaitu semen segar Sapi Simmental sebagai media yang akan diamati, minyak atsiri dan tris kuning telur sebagai bahan pengencer, asam sitrat, fruktosa, eosin $2 \%$ sebagai media pengamatan sperma hidup dan mati, formolsaline sebagai media pengamatan TAU (Tudung Akrosom Utuh), aquabidestillata, air hangat $\left(45-55^{\circ} \mathrm{C}\right)$, larutan HOST (Hipo Osmotic Swelling Test) sebagai media pengamatan MPU (Membran 
Plasma Utuh), $\mathrm{N}_{2}$ cair untuk membekukan semen, straw untuk mengemas semen dan tisu sebagai pembersih peralatan.

Alat penelitian yang digunakan yaitu beaker glass $400 \mathrm{ml}$ sebagai tempat pembuatan bahan pengencer, straw sebagai tempat semen, deck glass, tissue, batang pengaduk sebagai pengaduk bahan pengencer, satu set VB, tabung reaksi, water bath sebagai alat mempertahankan semen pada suhu $37-39^{\circ} \mathrm{C}$, mikroskop elektrik sebagai alat mengamati sperma, termometer sebagai pengukur suhu lingkungan, pipet tetes sebagai pengambil semen, objek glass sebagai tempat sperma yang akan diamati dibawah mikroskop, cover glass, $\mathrm{pH}$ meter sebagai pengukur $\mathrm{pH}$ sperma, pembakar bunsen sebagai pembakar sperma pada pengamatan sperma hidup dan mati, denominator sebagai penghitung jumlah sperma, container sebagai tempat pembekuan dan penyimpanan semen beku, kandang penampung dan keset kaki.

\section{Metode penelitian}

Metode penelitian yang digunakan adalah metode percobaan RAL dengan menggunakan 4 perlakuan dan 5 ulangan.

Perlakuan yang diberikan adalah :

$\mathrm{P} 1=$ Tris Kuning Telur+Minyak Atsiri 0,25\%

$\mathrm{P} 2=$ Tris Kuning Telur+Minyak Atsiri $0,5 \%$

P3 $=$ Tris Kuning Telur+Minyak Atsiri 0,75\%

P4 = Tris Kuning Telur+Minyak Atsiri 1\%

Peubah yang diukur

Pengamatan yang dilakukan setelah semen diencerkan adalah :

Motilitas: persentase spermatozoa yang bergerak progresif ke depan. Evaluasi dilakukan dengan cara mengamati spermatozoa pada delapan lapang pandang yang berbeda dengan mikroskop cahaya pembesaran 400 kali (Toelihere, 1993).

Viabilitas: dievaluasi dengan menggunakan pewarnaan eosin (Toelihere, 1993). Spermatozoa yang hidup ditandai oleh kepala yang tidak menyerap zat warna, sedangkan yang mati ditandai oleh kepala yang berwarna merah. Evaluasi dilakukan pada minimal 200 spermatozoa diamati dengan menggunakan mikroskop cahaya pembesaran 400 kali. Persentase spermatozoa hidup dihitung berdasarkan rumus :

$\%$ spermatozoa hidup $=$

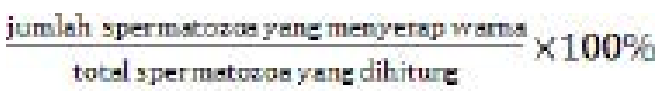

MPU (Membran Plasma Utuh): Evaluasi dilakukan terhadap keutuhan membran plasma spermatozoa. Evaluasi dilakukan dengan menggunakan metode hypoosmotic swelling test (HOST). Pengujian dilakukan dengan cara mencampur $0,1 \mathrm{ml}$ semen dengan 9,9 $\mathrm{ml}$ medium hipoosmotik. Setelah dicampurkan, sediaan diinkubasi dalam waterbath bersuhu $37^{\circ} \mathrm{C}$ selama 30 menit (Rodriquezgil et al., 1994). Evaluasi dilakukan di bawah mikroskop cahaya pada pembesaran 400 kali. Persentase MPU dihitung berdasarkan rumus :

MPU $=\frac{\text { sperma dengan eloor melekgkukg }}{\text { total aperna yang dihtumg }} \times 100 \%$

TAU (Tudung Akrosom Utuh): Evaluasi dilakukan terhadap keutuhan tudung akrosom spermatozoa yang ditandai oleh ujung kepala spermatozoa yang berwarna hitam tebal, apabila semen dipaparkan di dalam larutan $\mathrm{NaCl}$ fisiologik yang mengandung $1 \%$ formalin (Saacke dan White, 1972). Evaluasi dilakukan pada minimal 200 spermatozoa dengan menggunakan mikroskop cahaya pembesaran 400 kali. Persentase TAU dihitung berdasarkan rumus:

TAU $=\frac{\text { sperma de ngan alkosom berwarka }}{\text { cotal aperma yang dihtung }} \times 100 \%$

HASIL DAN PEMBAHASAN

Evaluasi kualiatas semen beku Sapi Simmental dilakukan sebelum pembekuan dan sesudah pembekuan. Pengamatan meliputi persentase motilitas, spermatozoa hidup, Membran Plasma Utuh (MPU) dan Tudung Akrosom Utuh (TAU). Hasil penelitian dapat dilihat pada Tabel 1. 
Tabel 1. Rekapitulasi hasil penelitian kualitas semen beku Sapi Simmental.

\begin{tabular}{lccc}
\hline \multirow{2}{*}{ Parameter } & Perlakuan & \multicolumn{2}{c}{ Pengamatan } \\
\cline { 2 - 4 } & & $\begin{array}{c}\text { Sebelum } \\
\text { Pembekuan }\end{array}$ & Setelah Pembekuan \\
\hline Motilitas & $0,00 \%$ & $64 \pm 2.24^{\mathrm{A}}$ & $43 \pm 2.24^{\mathrm{A}}$ \\
& $0,25 \%$ & $65 \pm 2.24^{\mathrm{A}}$ & $44 \pm 2.24^{\mathrm{A}}$ \\
& $0,50 \%$ & $68 \pm 2.24^{\mathrm{A}}$ & $47 \pm 2.74^{\mathrm{A}}$ \\
& $0,75 \%$ & $70 \pm 0.00^{\mathrm{B}}$ & $49 \pm 2.74^{\mathrm{B}}$ \\
& $1,00 \%$ & $72 \pm 0.00^{\mathrm{B}}$ & $53 \pm 2.24^{\mathrm{B}}$ \\
\hline Viabilitas & $0,00 \%$ & $77 \pm 1.64^{\mathrm{A}}$ & $63 \pm 5.08^{\mathrm{A}}$ \\
& $0,25 \%$ & $78 \pm 1.64^{\mathrm{A}}$ & $65 \pm 5.08^{\mathrm{A}}$ \\
& $0,50 \%$ & $81 \pm 1.37^{\mathrm{A}}$ & $67 \pm 5.56^{\mathrm{A}}$ \\
& $0,75 \%$ & $83 \pm 1.64^{\mathrm{B}}$ & $69 \pm 5.08^{\mathrm{B}}$ \\
& $1,00 \%$ & $86 \pm 1.67^{\mathrm{B}}$ & $72 \pm 6.07^{\mathrm{B}}$ \\
\hline Membran Plasma Utuh & $0,00 \%$ & $75 \pm 1.66^{\mathrm{A}}$ & $60 \pm 7.52^{\mathrm{A}}$ \\
& $0,25 \%$ & $76 \pm 1.66^{\mathrm{A}}$ & $61 \pm 7.52^{\mathrm{A}}$ \\
& $0,50 \%$ & $79 \pm 1.09^{\mathrm{B}}$ & $63 \pm 6.55^{\mathrm{A}}$ \\
& $0,75 \%$ & $83 \pm 1.66^{\mathrm{A}}$ & $65 \pm 6.45^{\mathrm{B}}$ \\
& $1,00 \%$ & $85 \pm 1.16^{\mathrm{B}}$ & $68 \pm 7.52^{\mathrm{A}}$ \\
\hline Tudung Akrosom Utuh & $0,00 \%$ & $73 \pm 1.11^{\mathrm{B}}$ & $58 \pm 5.43^{\mathrm{A}}$ \\
& $0,25 \%$ & $74 \pm 1.11^{\mathrm{B}}$ & $59 \pm 5.43^{\mathrm{A}}$ \\
& $0,50 \%$ & $77 \pm 1.14^{\mathrm{A}}$ & $61 \pm 4.32^{\mathrm{A}}$ \\
& $0,75 \%$ & $80 \pm 1.11^{\mathrm{A}}$ & $63 \pm 5.43^{\mathrm{A}}$ \\
& $1,00 \%$ & $83 \pm 1.13^{\mathrm{B}}$ & $65 \pm 5.50^{\mathrm{B}}$ \\
\hline
\end{tabular}

Keterangan: Superskrip yang berbeda pada kolom menunjukkan perbedaan yang sangat nyata $(\mathrm{P}<0.01)$.

\section{Persentase Motilitas Spermatozoa}

Hasil uji analisis ragam menunjukkan penambahan minyak atsiri kulit jeruk manis berpengaruh sangat nyata $(\mathrm{P}<0.01)$ terhadap motilitas spermatozoa sebelum dan sesudah pembekuan. Hasiluji lanjutBNT menunjukkan bahwa rataan motilitas tertinggi terdapat pada perlakuan P4 dan P3 dimana perlakuan P4 dan $\mathrm{P} 3$ berbeda terhadap perlakuan $\mathrm{P} 1$ dan $\mathrm{P} 2$ tetapi perlakuan P1 dan P2 memberi pengaruh yang sama terhadap motilitas spermatozoa semen Sapi Simmental. Hal ini menunjukkan semakin tinggi konsentrasi minyak atsiri kulit jeruk manis maka semakin tinggi persentase motilitas spermatozoa sebelum dan sesudah pembekuan. penurunan motilitas spermatozoa juga disebabkan karena perlakuan yang menimbulkan kerusakan dan kematian spermatozoa.

Daya gerak spermatozoa (Motilitas) merupakan salah satu penentu keberhasilan spermatozoa untuk mencapai ovum pada saluran tuba fallopi dan merupakan ukuran yang digunakan sebagai kesanggupan spermatozoa untuk membuahi sel telur. Semen Sapi Simmental sangat mudah mengalami kerusakan selama proses pembekuan karena terjadinya pembentukan kristal kristal es yang mengakibatkan kematian spermatozoa. Selama proses pembekuan semen kristal es yang terbentuk akan menyebabkan konsentrasi elektrolit meningkat di dalam sel yang akan melarutkan selubung lipoprotein dinding sel spermatozoa dan pada waktu thawing akan mengubah permeabilitas membran plasma sehingga spermatozoa mati (Toelihere, 1993).

$$
\text { Penurunan motilitas ini juga }
$$
dikarenakan berkurangnya persediaan energi spermatozoa yang digunakan untuk mempertahankan hidup dan mendukung 
pergerakan spermatozoa. Spermatozoa sangat rentan terhadap kerusakan sel akibat adanya perubahan tekanan osmotic secara tiba-tiba yang disebabkan oleh pencairan yang cepat selama proses thawing. Hanya spermatozoa yang mempunyai kemampuan daya membran plasma kuat yang mampu bertahan (Maxwell and Watson,1996).

Dari hasil pengamata motilitas dapat disimpulkan bahwa seluruh perlakuan layak untuk dilakukan IB karena memiliki motilitas tidak kurang dari 40\% Evans dan Maxwell (1987). Lebih lanjut menurut Zenichiro et al. (2002) menyatakan bahwa syarat semen yang layak IB memiliki dan motilitas individu post thawing adalah $40 \%$. Adanya perbedaan motilitas spermatozoa pada tiap perlakuan dapat disebabkan tingginya level penggunaan minyak atsiri jeruk manis di dalam bahan pengencer sehingga terjadi peroksidasi lipid. Menurut White (1993) bahwa hidroksinonenal merupakan salah satu peroksidasi lipid yang dapat menghambat glikolisis dan motilitas spermatozoa. Selain kerusakan yang ditimbulkan oleh peroksidasi lipid, penurunan motilitas dapat juga terjadi akibat beberapa faktor antara lain perubahan $\mathrm{pH}$ Medium, tekanan osmotik dan efek elektrolit dan non elektrolit (Toelihere, 1993).

\section{Persentase Spermatozoa Hidup}

Pengamatan persentase spermatozoa hidup dilakukan dengan melihat perbedaan warna spermatozoa pada preparat. spermatozoa yang tidak bergerak belum tentu mati sehingga tidak menyerap warna, sedangkan pada penafsiran dengan dasar bergerak dan tidak bergerak dianggap immotil (Kartasudjana, 2001). Pengamatan persentase spermatozoa hidup Kambing Boer perlu dilakukan karena merupakan syarat mutlak bagi terjadinya fertilisasi.

Hasil Pengamatan persentase spermatozoa hidup Kambing Boer menunjukkan nilai tertinggi adalah pada perlakuan P4 yaitu $86 \%$ sebelum pembekuan dan setelah pembekuan $72 \%$. Hasil analisis ragam persentase spermatozoa hidup mati sangat berbeda sangat nyata $(\mathrm{P}<0.01)$ baik pada pengamatan sebelum maupun sesudah pembekuan. Hal ini menunjukkan bahwa semen beku tersebutberkualitas baik. Toelihere (1993) yang menyatakan bahwa semen yang normal biasanya mempunyai persentase hidup minimal $50 \%$. Terjadi penurunan persentase hidup yang cukup tinggi dari sebelum dan sesudah pembekuan. Penurunan terjadi karena pengaruh fisik saat perlakuan yang menyebabkan kematian yang diakibatkan oleh gesekan antar spermatozoa, spermatozoa dengan dinding tabung, atau antara globul lemak dari kuning telur yang menyebabkan kecenderungan penurunan karena perbedaan tingkat pengenceran (Toelihere, 1993).

\section{Persentase Membran Plasma Utuh (MPU)}

Pengamatan Membran plasma Utuh penting dilakukan karena merupakan syarat mutlak keberhasilan fertilisasi Inseminasi Buatan. Apabila membran plasma rusak maka proses metabolisme akan terganggu, sintesa ATP tidak berjalan dengan normal dan dapat berakibat fatal bagi sperma sehingga terjadi penurunan motilitas dan daya tahan hidup spermatozoa Sapi Simmental.

Hasil analisis ragam Membran Plasma Utuh menunjukkan pengaruh minyak atsiri pada bahan pengencer bepengaruh sangat nyata $(\mathrm{P}<0.01)$ baik pada pengamatan sebelum maupun sesudah pembekuan. Nilai rataan Membran Plasma Utuh Sapi Simmental sebelum pembekuan tertinggi pada perlakuan P4 yaitu $85 \%$ dan setelah pembekuan yaitu $68 \%$. Hasil penelitian menunjukkan adanya penurunan kualitas spermatozoa dari proses pendinginan hingga pembekuan dan thawing.

Spermatozoa dengan persentase hidup yang tinggi menunjukkan persentase membran plasma utuh yang tinggi juga. Dijelaskan Tambing et al. (1999) bahwa spermatozoa dengan persentase hidup tinggi menandakan bahwa membran plasma masih utuh secara fisik, sehingga organel sel spermatozoa akan terlindungi, ion-ion untuk proses metabolisme dan kebutuhan zat-zat makanan tersedia. Menurut Supriatna 
dan Pasaribu (1992). Konsentrasi laktosa yang tinggi menyebabkan terjadi perubahan tekanan osmotik pada pengencer ke arah hipertonik yang menandakan molekulmolekul atau partikel-partikel di luar sel lebih banyak daripada di dalam sel sehingga terjadi pengeluaran air dari dalam sel

Menurut Maxwell dan Watson (1996), menurunnya motilitas spermatozoa juga disebabkan karena perlakuan yang menimbulkan kerusakan dan kematian spermatozoa. Selama proses thawing spermatozoa rentan sekali terhadap kerusakan sel akibat perubahan tekanan osmotic secara tiba-tiba yang disebabkan oleh pencairan yang cepat. Hanya spermatozoa yang mempunyai kemampuan daya membran plasma kuat yang mampu bertahan. Penurunan motilitas spermatozoa sebelum pembekuan mengalami penurunan yang disebabkan oleh faktor egg-yolk coagulating enzyme pada plasma semen sapi yang bersifat toksin dan cold shock. Penurunan motilitas ini juga dikarenakan berkurangnya persediaan energi spermatozoa yang digunakan untuk mempertahankan hidup dan mendukung pergerakan spermatozoa.

\section{Persentase Tudung Akrosom Utuh}

Pengamatan Tudung Akrosom Utuh penting dilakukan karena rusaknya akrosom dapat mengakibatkan hilangnya enzim enzim proteolitik dan kebanyakan terjadi pada saat pencairan kembali yang menyebabkan kegagalan Inseminasi Buatan (Valcarcel et al., 1997). Hasil pengujian analisis ragam menunjukkan pengaruh minyak atsiri pada bahan pengencer bepengaruh sangat nyata $(\mathrm{P}<0.01)$ terhadap persentase tudung akrosom utuh setelah pengenceran dan equilibrasi Persentase tudung akrosom utuh yang tertinggi pada perlakuan $\mathrm{P} 4$ sebelum pembekuan yaitu $83 \%$ dan $65 \%$ setelah pembekuan.

Hasil pengamatan menunjukkan persentase tudung akrosom utuh akan semakin tinggi jika terjadi peningkatan level minyak atsiri jeruk manis dalam pengencer semen Kambing Boer. Secara fisiologis terdapat hubungan antara motilitas dan keutuhan membran plasma serta daya hidup spermatozoa. Kerusakan membran plasma akan menyebabkan hilangnya enzim-enzim yang diperlukan (Salisbury dan Van DeMark, 1985). Faktor lain yang menentukan kualitas spermatozoa bila dilakukan thawing pada suhu yang optimal adalah difusi gliserol intraseluler terjadi lebih cepat dan pencegahan terhadap kejadian osmotic shock.

\section{KESIMPULAN}

Kualitas semen beku Sapi Simmental yang terbaik adalah dengan pada perlakuan P4, yaitu penambahan minyak atsiri kulit jeruk manis sebanyak $1 \%$ yang dapat mempertahankan dan meningkatkan kualitas Sapi Simmental. Masih diperlukan penelitian lanjutan dengan melakukan uji fertilitas semen beku Sapi Simmental untuk mengetahui tingkat keberhasilan Inseminasi Buatan.

\section{DAFTAR PUSTAKA}

Agusta, A. 2010. Minyak Atsiri Tumbuhan Tropika Indonesia. ITB, Bandung.

Anggraeny, Y. N., L. Afandhy dan Rasyid. 2005. Efektifitas Substitusi Pengencer Tris Sitrat dan Kolesterol Menggunakan Air Kelapa dan Kuning Telur Terhadap Kualitas Semen Beku Sapi Potong. Seminar Nasional Teknologi Peternakan dan Veteriner 2005.

Evans, G. and W. M. C. Maxwell 1987. Salamon's Artificial Insemination of Sheeps and Goats. Butterworths. London..

Fisher, K. and C. A. Phillips. 2006. The effect of lemon, orange and bergamot essential oils and their components on the survival of Campylobacter jejuni, Escherichia coli O157, Listeria monocytogenes, Bacillus cereus and Staphylococcus aureus in vitro and in food systems. J Appl Microbiol. 2006 Dec;101(6):1232-40. 
Gunawan, M. dan E. M. Kaiin. 2008. Kualitas Sperma Sapi Beku Dalam Media Tris Kuning Telur Dengan Konsentrasi Raffinosa yang Berbeda. Seminar Nasional Teknologi Peternakan dan Veteriner 2008.

Kartasudjana, R. 2001. Teknik Inseminasi Buatan Pada Ternak. Jakarta.

Maxwell, W. M. C. and P. F. Watson. 1996. Recent Progress in the Preservasion of Ram Semen. Animal reproduction.

Rizal, M. dan Herdis. 2008. Inseminasi Buatan Pada Domba. Jakarta. Rineka Cipta, Jakarta.

Rodriguezgil, J. E., A. Montserrat, and T. Rigau. 1994. Effects of Hypoosmotic Incubation on Acrosome and Tail Structure on Canine Spermatozoa. Theriogenology.

Saacke, R. G. and J. M. White. 1972. Semen Quality Tests and Their Relationship to Fertility. Proceeding 4th Tech Conf on $\mathrm{AI}$ and Reprod NAAB.

Salisbury, G. W. and N. L. Van DeMark. 1985. Fisiologi Reproduksi dan Inseminasi Buatan pada Sapi. Terjemahan R. Djanuar. Gadjah Mada University Press, Yogyakarta.

Salmah. N. 2014. Motilitas, Persentase Hidup dan Abnormalitas Spermatozoa Semen Beku Sapi Bali Pada Pengencer Andromed dan Tris Kuning Telur. Fakultas Peternakan Universitas Hasanudin. Makassar.

Supriatna, I. dan F. H. Pasaribu. 1992. In
Vitro Fertilisasi, Transfer Embrio dan Pembekuan Embrio. Pusat Antar Universitas, Institut Pertanian Bogor, Bogor.

Tambing, S. N. 1999. Efektivitas berbagai dosis gliserol dan waktu ekuilibrasi terhadap kualitas semen beku kambing Peranakan Etawah. Thesis Pascasarjana IPB-Bogor.

Toelihere, M. R. 1993. Fisiologi Reproduksi pada Ternak IPB Press, Bogor.

Valcarcel, A., M. A. De Las Heras, L. Perez, D. F. Moses and H. Baldassarre. 1997. Assessment ofthe acrosomal status of membrane-intact ram spermatozoa after freezing and thawing by simultaneous lectin/Hoechst 33258 staining. Anim. Reprod. Sci. 45: 299-309 .

White, I. G. 1993. Lipids and Calcium Uptake of Sperm In Relation to Cold Shock and Preservation : Areview. Reprod. Fertil. Dev. 5: 639-658.

Widjaya. N. 2011. Pengaruh Pemberian Susu Skim dengan Pengencer Tris Kuning Telur Terhadap Daya Tahan Hidup Spermatozoa Sapi pada Suhu Penyimpanan 50C. Sains Peternakan Vol. 9 (2), September 2011: 72-76.

Yuwanta, T. 2010. Telur dan Kualitas Telur. Gadjah Mada University Press. Yogyakarta.

Zenichiro, K., Herliantien dan Sarastina. 2002. Instruksi Praktek Teknologi Prossesing Semen Beku Pada Sapi. BBIB Singosari. Malang. 